\title{
20世紀前半期中国華南地域における 日本語定期刊行物
}

\author{
Peijun WU(呉佩軍 : Associate Professor of School of Foreign Studies South China Normal University) \\ 冈 wupeijun@m.scnu.edu.cn
}

(中国) 華南師範大学外国語学部日本語科副教授。日本近代文学史、日本植民地文化史。『竹内正一か描いた ハレビンの都市表象：「ギルマン・アパート点描」馬家溝」を中心に』(『跨境/日本語文学研究」第6号、2018)、編 著『伪满洲国文艺大事记』(『伪满时期文学资料整理与研究 研究卷』, 北方文藝出版社, 2017)など。

\section{Japanese Periodicals in South China in the First Half of the $20^{\text {th }}$ Century}

After the First Sino-Japanese War in 1895, the Japanese empire began to progressively implement its Southern Expansion Strategy. First, it occupied Taiwan and used it as a base for its southern expansion, and then penetrated into the major cities of South China, such as Xiamen, Guangzhou and Hong Kong. It went on to successively occupy major coastal cities in South China from 1938 to 1939, following the outbreak of the Sino-Japanese War. After the Pacific War broke out in 1941, Hong Kong was occupied. While engaging in political and economic aggression and military offensives against China, the Japanese empire also actively engaged in a propaganda war, using newspapers and magazines as important tools. In the first half of the $20^{\text {th }}$ century, the Japanese founded dozens of periodicals, most of which underwent three stages of management : the periods when they were run by the Japanese and Taiwanese press, by the Good-neighborly Association affiliated with the Taiwan Governor-General's Office, and by the military. Eventually, they became tools of the Japanese colonialists' efforts to control public opinion.

Keywords South China(華南地域), Japanese Periodicals(日本語定期 刊行物), Subject of Operation(運営主体), Southern Expansion (南進), Propaganda(プロパガンダ) 
華南(戦前の日本では「南支」と呼ばれる)という地域名には狭義と広義の定義が ある。狭義の定義では、五嶺山脈より南の地域、広東省・広西省・海南島などを 指すのに対して、広義の定義では、広東省・広西省・福建省・海南島・雲南省を指 す。『台湾と南支南洋』(1935年に台湾総督府官房調査課により編輯)においては、 「南支」の地理範囲を、福州・厦門・汕頭・広州などに駐在する日本帝国領事館管轄 の地域、即ち福建・広東・広西およびホンコン・マカオと明確に決められてい る。

1895年甲午戦争 (日清戦争)に勝った日本帝国は台湾を踏み台にして中国華南地 域に勢力を伸ばし、福建省を勢力範囲の中に納めた。その後、同じく華南地域に 属する広東省及びイギリスの植民地であるホンコンに進出していた。さらに 1938年から 1939年まで、日本軍が福建省の厦門・広東省の珠江デル夕、汕頭・海 南島など中国華南地域を占領した。太平洋戦争勃発後の1941年12月25日、ホンコ ンを攻め落とした。日本帝国による勢力拡張という背景の下で、20世紀前半期の 中国華南地域においては、数十種類の日本語定期刊行物が刊行されてきた。中に は、日本語文芸雑誌および、文芸欄を設けた新聞が数種類あった。これらの日本 語定期刊行物は、華南地域に対する日本帝国の文化政策と支配政策の一側面を示 すのにとどまらず、現地の日本人居留民の生活状況を記録しているものであり、 極めて重要な資料である。

1 鶴見祐輔『後藤新平』第 2巻(勁草書房, 1965), p.414.

\section{1 厦門における日本語定期刊行物}

甲午戦争 (日清戦争)以後、日本帝国は台湾を「南進」の基地にして、台湾対岸に あたる福建省などの地域に勢力を伸ばそうという「対岸政策」を「南進戦略」の一環 として打ち出した。台湾総督府も、植民地統治機関だけではなく、「南進」の主体 とも位置づけられていた。台湾対岸にあたる福建省などの地域に勢力を伸ばそう という「対岸政策」を「南進戦略」の一環として台湾総督府も、植民地統治機関だけ ではなく、「南進」の主体とも位置づけられていた。

厦門は福建省の経済と文化の中心地であり、華南地域の要衝でもある。ま た、この地は、台湾在住漢民族住民の故郷であり、台湾に最も近い大陸の都市で もあり、台湾と深い関係を持っている。したがって、廈門は、台湾総督府によ り、中国華南地域進出の拠点とみなされていた。1896年、第二代総督桂太郎は 「台湾経営」について、「台湾ノ施設経営八単二台湾ノ境域二止ラズ、更二大二対 外進取ノ確策ナカルベカラズ」「将来八更二進ンデ支那海ヨ圧シ、南清ノ沿岸卜密 接シ、南洋ノ列島卜交通シ、台澎ノ地利二、拠テ大二国勢伸長ノ策ヨ採ルベシ」、

「厦門二密接ノ交通习開始シ、福建一帯ノ地二潜勢习保ツベシ」 ${ }^{1}$ と、台湾を踏み台 
として福建省へ進出すべきだと明確に主張していた。次期の総督児玉源太郎と民 政長官の後藤新平も「台湾統治ノ既往及将来二関スル覚書」の中で、「南進ノ政策 全ウする二八内統治习励シ、外善隣ヨ努メ、可成国際上ノ事端ヨ生ズルヨ避ケ、 対岸清国並南洋ノ通商上二優勢 注意シ、ソノ帰向习察シ、反射的二台湾島民ノ安堵习図り、統治ノ目的习達スル」と、 厦門に対する支配と台湾統治と同一している。

このような方針に沿って、台湾総督府は19世紀末頃から正式的に厦門など福 建省の主要都市に勢力を伸ばし、「南進戦略」と「対岸政策」を実施した。1898年、 列強による中国分割という背景の下で、日本帝国は清朝政府と「福建不割譲条約」 を締結し、台湾の対岸にあたる福建省を勢力範囲に納めた。1900年は経済的拠点 としての台湾銀行厦門支店を設立し、さらに華南銀行・三五公司の支店を設け、 資本による拡張を計画した。経済の進出だけではなく、台湾総督府は日本領事館 とともに、福州の『閩報』(1897年に東巠同文会系の前田彪・井手三郎により中国人 経営の『福報』買収、『閩報』と改称 $)$ ・厦門の『厦門時報』(1903年創刊) と『全閩新日 報』(1907年台湾籍の江保生により創刊)などの新聞の刊行を援助し、文化工作も 展開した。江保生は「日本ノ文明 7 清国二鼓吹スルト同時二、日本ノ利益习擁護 シ、台湾人ノ便宜习図ル」ことを目的にして、台湾の名門林景仁、台湾公会長施 範其らに協力を得て、自ら主筆となり二名の中国人記者を雇い、中国語新聞を発 行し、発行部数700と伝えられた ${ }^{3}$ 。1909年、経営不振で財政状況が悪化した新聞 社は、在厦門日本領事館に援助を求めた。領事森安三郎は、反日的立場を取り「我 利権拡張二不尠防害卜相成る」厦門日報に拮抗シ、一方籍民ノ取締卜地方人士ノ 疑念水解」するために、『全閩新日報』を援助し、当該新聞をコントロールすべき だと主張し、「毎月二百円許宛台湾総督府か日本外務省機密費ヨリ融通习願度 し」と、政務局長倉地鉄之助に進言した。しかし、『厦門日報』が後ほど廃刊され たので、『全閩新日報』を援助する意義もなくなる。1914年9月、『厦門日報』の後 継者である『閩南報』が反日的立場を取るようになり、当該新聞がドイツ人に買収 される噂も出てきた。これに対応するために、日本外務省は『全閩新日報』に対し て、ようやく1914年11月から、一年九ヶ月ぐらい、月100円の補助金を援助して いた。

大正時代に入ると、台湾総督府民政長官の下村宏が中心として、学校、病院、 新聞を三本柱とした「文化工作」が積極的に推し進められた。下村宏は「南支一帯 ノ言論习左右シ、以テ我力南支政策ノ遂行习期セント欲セバ、須ラク対岸枢要ノ 地二於テ新聞ヨ刊行セサルヘカラス」としして、中国華南地域に情報宣伝用として の言論機関の設立、維持を主張した。1917年11月、民政長官下村宏、台湾銀行副 頭取中川小十郎は資金各一千円を醵出し、財団法人善隣協会を設立した。善隣協 会は台湾総督府の附属機関として、『南報』6等の新聞と雑誌を創刊した。1919年4
2 中村孝志編『日本の南方 関与と台湾』(天理教道 友社, 1988), p.7.

3 宮川次郎『厦門』(盛文 社, 1923), p.13.

4 「新聞雑誌操縦関係雑篹」 〈全䦨新日報』(第二 と第八画像目加ら) (所 蔵館：外務省外交史料 館), JACAR BB030406 14000.

5「台湾卜南支那卜八関 係及現在ノ施設並将来 ノ方針」/『台湾総督府 政況報告並雑報』(第十 八画像目加 ) (所蔵 館：外務省外交史料 館), JACAR B030416 52300.

6『南報』は1917年、善隣 協会の援助によって厦 門にて発行されていた 日本語版と中国語版の 週刊新聞である。1923 年廃刊。代表者山下伸 太郎と柏原秀吉。中下 正治『新聞にみる日中 関係史：中国の日本人 経営紙』( 研文出版, 1996)による。 
7 「新聞政策二関スル新計 画案」/新聞雑誌操縦関 係雑纂』(第九と第十画 像目から) (所蔵館：外 務省外交史料館）， JACAR B03040600400 8 宮川次郎『厦門』(盛文 社, 1923), p.158.

9 謝朧潤がジャーナリス というより、むしろ日 本のスパイであり、主 筆として在職中、「東 亜大同促進会」を設立 して、匪賊・ヤクザ・ 悪徳商人を丸め込み、 日本帝国主義の侵略の ために力を蓄えた。同 時に、現地の記者を雇 い、情報収集をさせ た。「厦門日籍浪人記 述」(『厦門文史資料』第 2号，1964)による。

10 沢重信(1899-1941)：

和歌山県出身。1916 年商科実業学校卒業 後、台湾歩兵聯隊入 隊。除隊後、台湾総 督府警察官就任、巡 查部長・新竹州警部 補・台北州警部補を歴 任。1934年、台湾総 督府派遣員として『全 閩新日報』社長代理就 任、厦門日本諜報機 関の機関員として活 動。1941年、軍統(中 国国民党の諜報組織) により暗殺。

11『新厦門指南』(華南新 日報社, 1941), p.123
月14日に外務省政務局第一課により作成された「新聞政策二関スル新計画案」で は、「既存新聞ノ持分ノ全部又ハ一部习買収シ従来ノ経営者习名義人トシテ継續セ シムルモノ何レニテモ臨時事情ニ依リ決スへキ」、「本邦側卜ノ関係八之ヨ極秘二 附シ全然支那人又八他外國人側ノ見地二在リテ議論スルモノノ如く装フヨ要ス」と 強調されている。このような方針に従い、1919年6月1日、善隣協会は江保生から 『全閩新日報』の経営権を買収したが、林爾嘉を名誉社長に、長子景仁を社長に、 江保生を顧問として、月三百円の補助金を給して彼らに引き続き新聞社を経営さ せた。このような短い過渡期を経て、善隣協会は新聞社の元の運営者を排除し、 全面的支配を行った。1922年『台湾新聞』の記者宮川次郎を主筆として、長谷川抱 星を社長として迎えた。長谷川抱星の運営の下で、『全閩新日報』は新聞を八版面 まで拡大するだけではなく日本語の週刊新聞『南支那』も創刊された8。

宮川次郎が転職した後の1925年には、明治大学専門部出身の台湾人謝朧潤年が 主筆に就任した。1928年1月、台湾総督府派遣員太田直作が一時主筆代理を委嘱さ れた。翌年4月、林爾嘉の第五子林履信が副社長兼主筆として就任したが、全職 員の反対で就任できなかった。同年7月、台南新報記者田中均が社長に任ぜられ

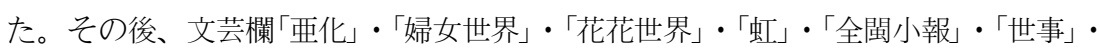
「流霞日刊」・咖啡座」などが続々と刊行されてきた。「九一八事変」(満洲事変)勃 発後、中国人の抗日運動が盛んになり、『全闆新日報』の購読者と広告掲載の収入 も急速に減り、新聞経営が行き詰っていった。そのために、田中は1934年7月に 辞職した。後、台湾総督府派遣員沢重信 ${ }^{10}$ が社長代理を勤めていた。善隣協会が 当該新聞に対する補助金を増加し、経営振興を図ろうとした。この資金援助に よって、新聞社は印刷機と活字を購入し、揭載内容を充実させた。一方、台湾総 督府は華南地域の情報収集の機関として、新聞社に「南支調査部」を増設した。

1937年7月「盧溝橋事件」勃発後、『全閩新日報』の社員が鼓浪嶼の公共租界地に 撤退し、しばらくにして報道活動を続けており、8月末頃台湾に引き揚げた。同 年11月、金門が日本海軍に占領された後、沢重信が来島した。12月1月に『全閩新 日報』の復活」第一号が発行されると同時に、プロパガンダ工作も再開された。 翌年5月厦門陥落後、日本海軍の負屓を得て、新聞社が厦門に戻り、星光日報社の 施設を占有し、6月4日に『全閩新日報』を復刊、中国語版面の六版面のほかに日本 語版面を二面増設した11。後、中国語の版面を4版面に縮小し、第一と二版面に同 盟社のニュース、第三版面に現地ニュースを揭載、第四版面に文芸欄を設けた。 新聞社は『全閩新日報』の他に、小型新聞の『華僑新報』、『民声報』および月刊誌『閩 鐸』なども刊行していた。

台湾総督府と軍部は『全閩新日報』を「宣撫工作」の道具として利用し、占領地 の中国人民衆に対する思想統制を行った。汕頭陷落後の1939年9月、台湾総督府は 「汕頭処理方針」を打ち出し、「全閩新日報、香港日報等の増発配布、放送、各種伝 
単等の撒布その他宣撫上必要なる情報宣伝を実施す」年と宣伝方針を定めている。

1941年9月26日、『全閩新日報』社長沢重信が暗殺された後、日本海軍特務部の 機関員である福士繁吉が社長に就任した。その後、世盛治平が社長に任ぜられ た。そのため、当該新聞も厦門駐在日本海軍司令部の機関紙となったのである。 太平洋戦争勃発後、『全閩新日報』の日本語版に掲載された記事は、四種類に分類 される。一つ目は「大東亜共栄圏」に対する宣伝、二つ目は、重慶政府および米英 に対するマイナスな報道、三つ目は戦争協力関係の報道、四つ目は、厦門の配 給、物価などの報道である。

日本敗戦後の1945年9月、『全閩新日報』が廃刊された。

\section{2 広州における日本語定期刊行物}

中国華南地域随一の港と第一位の大都市として栄えた広州は、アヘン戦争後、 その地位がホンコンに取って変わられた。日本の商社と居留民もホンコンに集 中していたが、1880年代後半から、ようやく広州に北上した。その後、日本と 広州の貿易の規模の拡大とともに、広州の日本人居留民の人数も次第に増えて、 1890 年の 10 余人から 1907 年の 200 余人に急増した ${ }^{13}$ 。第一次世界大戦勃発後、日本 と広州の貿易額がさらに伸びて、日本人居留民の人数も一段と増加し、1930年 500名を超えた。日本人居留民の移住とともに、ジャーナリストや知識人も広州 を訪れてきた。明治時代と大正時代、竹越与三郎、岡千仞、村松梢風などの文化 人が広州を訪れた後、自分の経験に基づいて遊記や随筆などを書き残した。 ジャーナリストの来原慶助が1916年11月に『南国報』、東洋史研究者である藤田豊 八が1918年に『嶺南新報』を、平井真澄と下田徳之助が1923年6月に『広東日報』を 創刊した。

1937年中日戦争勃発後、日本人居留民が一時的に国内に引き揚げたが、1938年 広州陥落後、再び戻った。その人数が1939年の4706人から 1940年の7183人、 1943 年 8 月の 11731 人 (台湾人と朝鮮人を含め)へと急増した ${ }^{14}$ 。戦時中、久米正 雄、真杉静枝、長谷川時雨、円地文子、吉川晋、長谷川春子などの文芸家が広州 を訪問して、「南方紀行」「南支の春」などの遊記を創作した。

1938年10月21日広州陥落後 ${ }^{15}$ 、第21軍 (翌年南支派遣軍と改称)司令部が広東特 務機関、海軍特務部、広東総領事館、台湾総督府などの協力機関とともに、植民 支配体制を確立した。宣伝戦の機関として、特務機関の成員と従軍記者および兵 隊作家からなった軍報道部も設けられた。同年、第21軍司令部は宣撫部、宣無 処、宣㨗班を設立した。後、傀儡政権としての汪兆銘系広東省政府も宣伝処を設 けた。広州は華南日本軍占領地域の政治・経済と文化の中心地となった。多くの
12 角田順編,「解説」『現 代史資料 10 日中戦争3 (みすず書房， 1964）, p. 447

13 外务省通商局编『清国 事情』第二辑(『清国事 情』第式輯) (外务省通 商局, 1907), pp.849850.

14 平野健『広東居留民団 誌』(南支日報社, 1945), p.34.

15 第21軍は、1938年10 月12日にバイアス湾 に上陸し、10月21日 に広州を攻め落と し、11月2日に仏山な ど珠江デルタの主要 都市を、翌年6月に汕 頭を占領した。 
文芸団体が成立し十数類の新聞・百種類の雑誌が広州および周辺都市で刊行さ れ、数多くの文学作品が創作されてきた。岩井武男などの文化人も「共栄会」中 日文化協会」などの親日団体を結成し、協栄印書館を設立した。協栄印書館とは日 本人によって運営された出版社であり、主任が桑野敬治、編集長が林欣欣であ る。これらの団体によって、数多くの新聞と雑誌が創刊された。

広東省日本軍占領地域で刊行された雑誌は二十数種類に達した。協栄印書館は 「共存共栄」を宣伝する書籍だけではなく、『婦女世界』、『新亜月刊』、『南星』など の中国語雑誌を刊行し、日本軍による支配を美化し、「大東亜聖戦」を鼓吹した。 東亜連盟広東分会という機構も『東亜連盟月刊』、東亜連盟画報』、『東連周報』、『精 神」などの中国語雑誌を刊行し、「中日親善」を宣伝した。汪兆銘系広東省政府宣伝 処も『協力月刊』、『新広東』、『協力半月刊』、『協力旬刊』を刊行した。華南公論雑 誌社が月刊『華南公論』、南洋雑誌社が『南洋雑誌』も刊行した。同地域で刊行され た新聞も二十数種類に達した。広州では、『広東迅報』、『南支日報』、中山日報』、 『民声晚報』、『粤江日報』、『粤声報』などの新聞が次々と創刊した。汕頭にも、『嶺 東日報』と『潮梅新聞』・粤東報』および日本語版の姉妹紙『汕頭日報』が刊行され た。

中国語の『広東迅報』社と姉妹紙の日本語の『南支日報』社は善隣協会によって、 第21軍報道部からの支持を得て、宣伝戦の一環として設立されたのである。両紙 とも「南支派遣軍」の機関紙として、日本軍の武勇の賛美と戦争の美化に力を入れ た。

1938年11月、唐沢信夫など21軍報道部の部員が、長堤靖海路にある胡文虎所有 の「星粤日報社」の作業場を徴用し、そこで『広東迅報』を創刊した。

『南支日報』は1938年12月に『広東迅報』の日本語コラムとして創刊され、1939 年4月29日に独立し、1945年8月15日廃刊された。同新聞は『広東迅報』に従属して いるので、両社の従業員は同じである。社長唐沢信夫(長野)、和文編集長吉野昇 之助(群馬)、漢文編集長林宝樹(台北)、社会部長山本力(岡山)、学芸部長池田享 (福岡)、対華部長徐毓英(新竹)、写真部長田中幸一(大阪)である。当該新聞社は社 長室、編輯局、庶務課、会計課、新聞課、印刷課、写真部、広告課、工場を設け た。唐沢信夫は「大正十二年三月早稲田大学法学部 7 卒業、同年四月東京朝日新聞 二入社、同十三年七月転ジテ新愛知新聞二入ル、同十四年十月同社 7 退キ台湾日 日新報社二入社、ソノ後新高新報ヨ創立、同社社長トナル。昭和十年十一月台北 市会議員二当選、同十三年広東に渡り広東迅報社長卜ナリ、『広東迅報』と『南支日

16『臺灣人士鑑』(興南新 聞社, 1943), p.95
報』を創刊した ${ }^{16}$ 。彼は新聞社を経営すると同時に、広東特務機関の嘱託とし

て、メディア統制に携わった。

『南支日報』は日本占領軍、日本人居留民と台湾籍の中国人にむけて発行する日 本語の新聞であると同時に、「南支派遣軍」の機関紙でもある。したがって、軍 
事・政治と経済の報道を重点においた。独立当初の『南支日報』は四枚紙の小型新 聞であり、第一版面は、華南戦線と南洋戦場の記事、第二版面は、重慶政府およ び米英に対するマイナス報道、第三版面は、広東省日本人居留民の戦争協力、宣 撫班による宣掹活動についての報道、第四版面は文芸欄である。太平洋戦争勃発 後、物資の久乏が筫しくなり、新聞の紙面も縮めざるを得なくなった。このよ うな背景のもとで、『南支日報』も1943年11月から、二版面に縮小し、同盟社の ニュースと広東関連のニュースだけ載せるようになった。

『南支日報』の文芸欄には、文芸評論、俳句、随筆、体験談、連載小説のような 文芸作品が揭載されている。これらの文芸作品は内容別に見ると、宣撫活動に関 する作品、重慶政府と米英を非難する文芸作品、広東を題材にする作品、「大東亜 戦争」協力を鼓吹する文芸評論などがある。執筆者は四種類に分けられる。一つ 目は、当該新聞社の記者である。二つ目は、一般の日本人居留民と台湾人などで ある。三つ目は、火野莘平のような「南支派遣軍」報道部と宣無班の成員及び日本 軍の兵士などである。四つ目は、武者小路実篤、打木村治、福田清人、新田潤、 真杉静枝など日本国内の作家である。

陥落後の広州で刊行された代表的な日本語文芸雑誌は、『兵隊』・南支文学』・ 『広東日本青年』があげられる。『兵隊』は「南支派遣軍報道部」により刊行された雑 誌である。当該雑誌は1939年5月より1944年5月にかけて、全部39号発行され た。当時、広東迅報社により印刷され、中国の前線で無料で日本兵士に配布さ れ、一時は出版費の問題で七ヶ月も停刊になり、最終的に陸軍恤兵金によって運 営されていたのである。執筆者は南支派遣軍の兵士が主な担い手であったが、作 家、画家、新聞記者、相撲選手、俳優など、さまざまな分野で活躍している人も いる。また、一部の現地中国人・台湾人が書いたものが見られる。誌面構成は多 様化しているが、同盟通信社などからの記事、兵士や作家たちの投稿作品(俳 句・和歌・詩・俗謡・小説・エッセイ・現地研究リポート・座談会・漫画等)など が主として掲載された。編集者は火野葦平のほか、池田享、安田貞雄、下田徳幸 などがいる。

1940年7月26日、日本第二回近衛内閣が「基本国策要綱」を定め、「大東亜新秩序 の建設」と「国防国家体制の整備」を基本国策とした。様々な組織が創設され、文 芸団体機関も改造された。この背景の下で、1941年末頃、広州の日本植民主義当 局が新しい文芸団体の設立を準備した。翌年2月、軍報道部と共栄会の主導の下 で、「広東文話会」が設立されそして、広州周辺の各都市にも分会が設けられ、事 務所が広州市西湖路75番地広東共栄会協栄印書館内に設置された。「広東文話会」 の中には、文学、絵画、演劇、音楽、写真・編纂等の分会が設けられた。当該文 話会は「決戦下に於ける文化翼賛ノ一翼トシテ国策二沿ヘル大東亜文化ノ創造並び 二発展二努入健全ナル趣味娛楽习養成スルト共二日華文化ノ提携交流 
17 『華南商工名人録』(華 南商工名人録発行所, 1943), p.189.

18 八木沼丈夫（1895 -1944)は、ジャーナ リス卜、歌人。1917 年渡満、大連の『満洲 商業新報』の主筆とし て新聞の運営に携 わった。1932年、「満 洲国」の宣伝工作を担 当した。1937年「盧溝 橋事変」勃発後、日本 軍の軍属として、華 北地域の宣撫活動を 指導した。1940年 代、広東に南下し、 華南地域の宣撫活動 に従事した。

19『華南商工名人録』(華 南商工名人録発行所, 1943), p.191.

20 南支文学社 (編)『南支 文学』創刊号(南支文学 社, 1944), p.3.

21 前掲注, p.163.
皇国民ノ責務に応へムトス」というスローガンを提出した。「文化一般ノ研究調査 紹介作品発表、諸展覧会鑑賞会ノ開催、文化活動二依儿軍人援護事業、中国文化 人卜ノ提携」艺事業とした。幹事長は池田享、常務理事は稲岡暹である。

「広東文話会」の他に、ジャーナリストの八木沼丈夫 ${ }^{18}$ は主宰として1942年12月 21日に「短歌中原広東支社」を成立し、沙面英租界一号にある八木沼の邸宅にて定 期的に句会の例会を行っていた。この文芸団体は「大東亜戦争決戦期間二於ケル 大陸文化の翼賛二寄与シ併セテ戦陣短歌ノ興隆二資スルト共二剛健ナル短歌道 確立シ会員相互ノ高雅ナル友情二結ブヨ以テ目的卜ス」、「戦陣短歌二依ル軍人援 護事業、短歌研究會の開催」19を事業の内容とする。他に、亜熱带句会と珠江句会 もある。

広東文話会や「短歌中原広東支社」の作家たちは自分の作品を発表するところを ほしがった。このような背景のもとで、池田享の提議によって、1944年9月、 『南支文学』が発刊された。この雑誌は「決戦に相應しい現地文學を創造し建設す ることに、傍眼もふらず直往したいと念じた。」20という主旨を打ち出した。編 集者たちは「編輯後記」において、「此度の大東亜戦争は、東亜共栄圏建設の積極 的な目的を持つた創造的聖戦であるから、われわれ現地の文化面に於ても、現地 文化の問題を聖戦の眞意に副つて押し進めることは、聖戦遂行上、一つの役割を 占めるものでなくてはならない。従って、われわれが文化面に於て、殊に現地 の特殊文化面に於て、文化に課せられた聖戦の要請する所を間違ひなく認識しそ れを雑誌編輯の上に實践的に生かすならば此種文化雑誌の刊行は積極的意義を持 つものと思ふ。」現在中国に於ける広東の位置の特異性及び我々がいまこの現地 に於いて果たすべき大東亜の文化的役割の一部署を痛感する。戦ひへの挺身性が 『表現』の前にある。ここで始めて雑誌の存在は一つの戦果としての役目を果し、 大東亜文化の全体を結ぶ契機とさへなる」 ${ }^{21}$ と唱えた。この発刊主旨と編輯後記か ら見机ば、『南支文学』の大東亜戦争のために奉仕する目的がさらに明確的になる ことが分かる。『南支文学』雑誌の誕生は、戦時下の占領軍報道部と共栄会および 広東文話会の意図と「南支文化」への構想を反映したものであり、権力に左右され たこの雑誌はすぐにロパガンダの道具になった。広東を「大東亜聖戦」の基地に するという国策が、『南支文学』では文化として扱われている。言い換えれば、 プロパガンダに文化の衣をつけるのである。

創刊号の誌面構成は、総合文学と現地文学がバランスよく配置されている。 具体的に言えば、前者は評論「文化の交流史的意義」(清水耕)、詩「歴史」(菊田孝) と「雑感」(張緩詩)、短歌「前線演奏」(松下哲)、俳句「年木割る」(岡本芳江)、詩篇 「女媧(序章)」(どいひろひと)、小説「胎動」(河内山淳一)、「白い手袋」(前川春 雄)、「あうんよ心の眼をひらけ」(七葉樹時雄)、「日語助手」(水落喜久子)からな り、後者は「留学生」(山辺耕造)、「榕樹部落」(石田一郎)、「花子」(池田享)が挙げ 
られる。『南支日報』は「南支文学の中に潜むもの」(1944年4月15日)において、池 田享の「花子」、山辺耕造の「留学生」、石田一郎の「榕树部落」などの現地文学を分 析し、日本人による実践活動を通じて新しい文化形成への境地を開拓していくと ころに大東亜文化造立への具体化と尖兵的任務が興へられるわけであると評して いる。

同誌の同人は、大きく二つに分けられる。一つは、池田享、石田一郎、桑野 敬治、後藤彦十郎、清水耕一、前川春雄など広東文話会の役員である。二つは、 堤紫海、染谷信次、菊田孝、大谷喜左治、水落光博、米谷實、河内山淳一、土井 博仁、神山時雄、水落喜久子、春野隆弘など日本人居留民である。前者は日本占 領軍報道部の支持を得て、『南支文学』の編集と運営などの業務を担当している。 とくに、池田享が同誌を左右している。

池田享は福岡出身、1938年軍人作家として広州にやってきた。彼は「南支文学」 の編集長だけではなく、『南支日報』の学芸部長、雑誌「兵隊」の編集長、広東文話 会の幹事長など兼任していた。1941年、広州周辺地域の抗日軍を討伐することを 描いた作品を創作し、作品集『デルタ帰還作家・純文学叢書』第2回(六芸社, 1941)を出版した。この作品集は汪兆銘系部隊による討伐と抗日軍の降伏行為を 美化し、川田指導官の武勇を讃えたものである。

上述した雑誌の他に、『広東日本青年』も「広東日本青年団」の機関誌として 1942年7月31日から19月16日まで、合計2号発行されていた。発行人は平井長幸、 印刷所は南支日報社である。編集者は「巻頭言」において、「戦ひと建設の時代 に、我々はその各々の職場を通じて日本の対外的経済触角の一つとして現地にあ る。我々は会社員、店員、技術員たる職能を果たすと共に東亜を解放し建設する 日本の現地青年として如何にその責任を果す可きかを種々企図してるのである。 その企図の一つが復をなしこのささやかなる雑誌が世に出るのである。」22と戦 争協力と東亜民族解放を鼓吹している。執筆者は広東日本青年団の成員の他に、 広東特務機関長矢崎勘十、南支日報社長唐沢信夫、「満洲国」高級官吏佐藤慎一、詩 人堀口大學などもいる。掲載される文章の体裁から見ると、論説文、詩歌、随 筆、紀行文などが挙げられる。内容から見ると、広東の名所・景色を描いたも の、戦争を美化するもの、武道・勤皇を論ずるものに分けられている。

\section{3 ホンコンにおける日本語定期刊行物}

漁村だったホンコンは1842年にイギリスに割譲された後、イギリスの「極東 支配の拠点」・東アジアとヨーロッパを結ぶ要衝・極東一の通過貿易港となっ た。日本人の使節と留学生の殆どがホンコンを経由してヨーロッパヘ行くこと 
23 陳湛碩・楊詠賢『香港 日本関係年表』(香港教 育図書公司, 2004), p.78.

24 中下正治『新聞にみる 日中関係史：中国の 日本人経営紙』(研文出 版，1996)，p.16.

25 東亜同文会編『対支回 顧録 (下)』(原書房, 1968), p.1010.

26 宋斐如『日本戦時外交 内幕』（時代書局， 1940), p.217.

27「香港日報社は……抗 日渦中二在りテヨク 帝國ノ眞意、事變ノ 真相宣傳普及二努么 人外敵側ノ虚偽宣傳 ヨ破砕シ新聞紙卜シ テノ使命二立脚シ健 闘シ来リタル。」(台 湾総督府編『湾総督府 事務成績提要』第47編 (成文出版有限公司, 1985), p.724.)

28「貫徹新聞使命, 誓言 獻身奉公」(『香港日報。 1943.1.7).

29 「(香港日報』は)軍ノ 指導援助)下二十二月 二十七日和漢英各紙共 復刊セラレタリ尚英文 紙ハ従来週刊ナリシ 軍二於テ敵産トシテ接 収セル抗日紙英文サウ ス・チャイナモーニ ングホスト社ノ設備 ノ利用ヨ軍ヨリ許容七 ラレタルヨ以テ之ヨ 支社に當テ日刊ホンコ ン・ニューストシテ發 足セリ同社八香港占領 後二於ケル善後處置機 関二協力シ宣傳宣撫上 ノ唯一ノ機関トシテ活 躍ヨ遂ゲタル。」(台湾 総督府編『湾総督府事 務成績提要』第47編(成 文出版有限公司, 1985), p.725.)
になる。1873年、日本ホンコン領事館が設置された。その後、日本人の商人、労 働者、風俗業者、旅行者も続々と訪机てきた。三菱・住友・横浜正金銀行なども ホンコンに進出した。日本人居留民は 1875 年の 13 人から 1909 年の 406 人 23 に増 え、1910年代に入ると、1000人以上に達した。このようにして、読者群の存在 によって日本人向けの新聞を発行する基盤が出来上がった。

ホンコンの日系新聞は三つあった。即ち、1899年刊行された中国語新聞『東 報』、1909年刊行された『香港日報』、1921年から1922年まで刊行された「南支那 新報」(社長平井真澄)である。中では、存続期間が最も長いのは『香港日報』であ る。創始者の松島宗衛は東亜同文会系統のジャーナリストで、元々営口の『満洲 日報』社の副社長として新聞社の事務を担当した。1909年『満洲日報』が廃刊され た後、『万朝報』の特派員として香港視察に来た際、香港日本領事館から援助を得 て、『香港日報』を創刊した。1909年9月1日創刊当初の『香港日報』は四枚紙の小型 新聞である。社長松島宗衛、編集幹部井手元一及び松田某、一日発行部数300500部、発行所香港大馬路94号、印刷所嘉士敦印刷所である24。

大正十年十一月内地に歸り、金鵎学院の教授たりしが、晚年は郊北豐島區長仲 町に穏棲し昭和十年二月五日竟に逝く25。元香港領事館員で編集幹部を兼ねた井手 元一が後を引き継いだ。井手元一は、『香港日報』の紙幅を4枚から6枚に拡大し、 香港事情を紹介する『香港案内』を1000部発行した。1927年3月1日、『香港日報』は 小型の新聞から一般新聞と昇格された。1937年12月から、『香港日報』の第四版面 が中国語と変更され、翌年6月、『香港日報』中国語版が独立した。その後、中国 語版と日本語版が何れも四枚紙の新聞として刊行された。

1938年、『香港日報』の経営権は台湾総督府付属の善隣協会の手に移った。「侵 略戦争が拡大した背景の下で、日本政府は、国際宣伝を強化する方針を打ち出 し、『香港日報』の経営権を台湾総督府の手に移し、運営費用も総督府に負担させ ることに決めた。このように、『香港日報』は日本政府の対外宣伝の機関誌となっ た」26。

1938年11月1日、『台湾日日新報』の記者である衛藤俊彦が井手元一の代わり に、『香港日報』社の社長に就任した27。

1939年6月27日、英語版の『Hongkong News』が発刊された。『香港日報』は 1939年9月に東京に支社を設け、大阪に支局を設立した。12月15日、中国語の週 刊誌『香港週報』の創刊号も発行された。衛藤俊彦時代の『香港日報』は、「戦争と建 設を全面的に支持し、国策の遂行に貢献を捧げることは、新聞人が担う天職と最 高最大の神聖なる使命である」 ${ }^{28}$ と主張し、戦争に協力したのである。

1941年12月ホンコン陥落後 ${ }^{29}$ 、日本の香港総督部は抗日の立場を取った新聞社 を閉鎖すると同時に、新聞整理と合併を行った。その結果、『香港日報』・南華 日報』・香島日報』・『華僑日報』・『東亜晚報』・无成報』の六紙しか残されなかっ 
た ${ }^{30}$ 。『香港日報』は唯一の日系新聞であった。日本の香港総督部と占領軍当局の 「代弁者」となった『香港日報』は、イギリスによる植民支配を攻撃すると同時に、 「大東亜共栄圏」の思想を宣伝し、日本軍の支配を美化するという編集方針を打ち 出した。

『香港日報』日本語版には文芸欄が設けられ、随筆・俳句・文芸評論・連載小説 のような文芸作品が掲載されている。これらの文芸作品は内容別に見ると、「大 東亜戦争」を鼓吹する作品、ホンコンと広東に関する作品、「南方」に関する作品 などがある。執筆者は三種類に分けられる。一つ目は、当該新聞社の記者、総督 府報道部の職員、香港満鉄事務所などの職員、一般の日本人居留民などである。 二つ目は、火野莘平のような「南支派遣軍」報道部の職員などである。三つ目は、 大佛次郎、片岡鉄兵、打木村治、福田清人、中山義秀、戸川貞雄、寶井馬琴など 日本国内の作家である。敗戦色が濃くなった1945年、日本人の土気を鼓舞するた めに、『香港日報』は一連の戦争小説を連載していた。中には、もっとも好評され たのは、大佛次郎の短編小説「残った一枚の切札」(1945年4月24日と25日)であ る。当該小説は仏首相クレマンソーと司令官フェルディナン・フォッシュの功績 を讃えたものである。第一次世界大戦末期の1918年、ドイツ軍の大攻勢により、 フランスが危機的状況に陥った。この瀬戸際において、クレマンソーが内閣閣 僚の反対を押し切り閑職にあったフォッシュを起用した。連合軍総司令官に就任 したフォッシュは首相の期待を無にせず、ドイツ軍の進撃を阻止し、勝利に導 いた。この小説の裏面には、フォッシュのような優れた将軍が日本軍を率いて 退勢を反転させるという作者の期待が込められている。

香港日報社は『香港日報』を刊行するのみならず、雑誌も発行していた。1945 年4月1日、香港云咸街1-3号にて日本語の月刊誌『読物と解説』を発刊し、同年6月1 日まで合計3号刊行した。編集者は「発刊の辞」において、「我々は時局の推移を正 しく認識するとともに、故国は如何に戦っているのか、皇国打倒を叫ぶ敵はい かなる態勢をとりつつあるか、更に戦局の帰趨に少からざる影響力をもつ彼我新 兵器の実体は如何一等に関してもある程度の知識を持たなければならない。更に 明日の戦力培養のため軽い読書をもって今日の疲労を愈した」 ${ }^{31}$ と創刊の主旨を打 ち出した。時評(朝日新聞社欧米部深沢長太郎担当)、支那随想(朝日新聞社東亜部 高道一雄担当)香港経済(朝日新聞社経済部千早健太郎担当)などのコラムを設け、 従軍作家中野実の長編小説『撃滅提灯』を連載していた。

『香港日報』と附属雑誌の他に、『香港青年』(1911年から1913年まで、日本青年 会により刊行) と『香港東洋経済新報月刊』(1944年6月1日から 1945年1月まで、香 港東洋経済社により刊行)の日本語雑誌、『写真情報』隔月刊(1943年10月14日か ら、香港総督部報道部宣伝班により刊行)の中国語雑誌があげられる。『香港青年』 に掲載されたのは評論文・詩歌・随筆・感想文など何れも短い文章で、執筆者は
30 李谷城『香港中文報業 發展史』(上海古籍出版 社, 2005), pp.286287.

31 香港日報社編『読物と 解説』創刊号(香港日報 社, 1945), 
日本青年会の成員・軍人などである。『香港東洋経済新報月刊』は経済関連の ニュースを載せるのに対して、『写真情報』は時局写真と説明文を掲載するもので ある。

\section{4 終わりに}

華南地域三大都市としての厦門・広州・ホンコンにおいて刊行された日本語定 期刊行物は、共通点を持っている。刊行物の関係からみれば、新聞は主体的地位 に立つのに対して雑誌は従属的な存在である。新聞のほとんどは宣伝戦の道具と して領事館や占領軍当局により重要視されたが、雑誌は新聞社に附属し或いは同 人雑誌である。そのため、新聞社は、文芸雑誌を刊行し、或いは雑誌の編集を指 導するのである。運営主体から見れば、外務省あるいは台湾総督府附属の善隣協 会から軍報道部へと変わっていった。善隣協会により運営された日本語の定期刊 行物が、日本占領軍の支配下に置かれ、占領軍当局の機関紙に改造された。この 運営主体の変化は、台湾総督府台湾総督府が「南進政策」における自主性を失い、 「主役」から「脇役」とと転落したことを示す。機能面では、定期刊行物は、日本人 居留民に対して、上意下達と戦争動員を行い、宣伝戦をバックアップした道具の みならず、情報收集の任務を担うものである。定期刊行物の発行により、華南全 域において、メディア統制と情報収集のネットワークも構築された。

一方、華南陥落地域における三大都市の位置づけにより、日本語定期刊行物の 役割と地位も異なる。厦門は、華南地域に進出した日本勢力の随一の拠点となっ たが、1938年広東沿海地域陷落後、その重要性が落ちた。広州は華南地域の中心 地であり、陥落後も日本軍により同地域の中核的都市と位置づけられた。ホンコ ンは東洋の重要都市だったはが、1941年12月陥落後、一般的な都市と変わった。 このような背景の下で、厦門とホンコンで刊行された日本語定期刊行物は、同地 においてしか影響力があるものであるが、広州の定期刊行物は、華南全域で発行 されたものである。

付記この文章は中国国家社会科学研究基金重大課題「近代以来中日文学関係研究と文献整理 (1870-2000)」(17ZDA2777)の段階的研究成果である。

\section{参考文献(Bibliography)}

日本青年会編 (1911-1913)『香港青年』第7-8号、第11-12号、第20号。香港：日本青年会. Nihon, Seinenkai (1911-1913) HongKong Seinen.Vol. 7-8, Vol. 11-12, Vol. 20. HongKong: Nihon 
Seinenkai.

宮川次郎(1923)『厦門』, 台北：盛文社. Miyagawa, Jirou(1923) Amoi. Taibei : Seibunsha.

南支派遣軍報道部編 (1939-1944)『兵隊』第1号-第39号, 広州：南支派遣軍報道部. Nanshi Hakengun

Houdoubu(1939-1944) Heitai Vol. 1-Vol. 39. Guangzhou : Nanshi Hakengun Houdoubu.

南支派遣軍報道部 (1940)『南支派遣軍』。東京：国際報道工芸. Nanshihakengunhoudoubu(1940)

Nanshihakengun. Tokyo : Kokusaihoudoukougei.

華南新日報社編 (1941)『新厦門指南』，厦門：華南新日報社. Huanan。Xinribaoshe(1941) Xinxiamen

Zhinan. Xiamen : Huananribaoshe.

広東日本青年団編 (1942)『広東日本青年』第1号-2号. 広州：広東日本青年団. Kanton Nihon

Seinendan (1942) Kanton Nihon Seinen. Vol. 1-2. Guangzhou : Kanton Nihon Seinendan.

『南支日報』(南支日報社, 1942-1944). Nanshinippou(Nanshinippousha, 1942-1944)

『香港日報』(香港日報社. 1942-1945)。.Hongkongnippou(Hongkongnippousha. 1942-1945)

南支文学社編 (1944)『南支文学』創刊号. 広州：南支文学社. Nanshi, Bungakusha(1944) Nanshi

Bungaku.Vol. 1 (1), Guangzhou : Nanshi Bungakusha.

東洋経済新報社編 (1944)『軍政下の香港：新生した大東亜の中核』, 香港 : 香港東洋経済社. Toukyou

Keizai Shinpousha (1944) Gunseikano Hongkong: Shinseishita Daitouano Chukaku.

hongkong: Hongkong : Toukyou Keizai Shinpousha.

香港日報社編 (1945)『読物と解説』第1-3号, 香港：香港日報社. HongKong. Nippousha(1945)

Yomimono to Kaisetsu. Vol. 1-3. HongKong : HongKong Nippousha.

平野健 (1945)『広東居留民団誌』, 広東：南支日報社. Hirano, Takashi(1945) kanton kyoryumindanshi, Kanton: Nanshinippousha.

鶴見祐輔 (1965)『後藤新平』第2巻,東京：勁草書房. Tsurumi, Yuusuke (1965) gotoushinpei,tokyo： keisoushobou.

中村孝志(1988)『日本の南方関与と台湾』, 奈良 : 天理教道友社. Nakamura, Takashi(1988) Nihon no Nanpoukanyo to Taiwan.nara: Tennrikyoudouyuusha. 